\title{
Discovery of Ophiostoma tsotsi on Eucalyptus wood chips in China
}

\author{
Joha W. Grobbelaar ${ }^{1}$, Z. Wilhelm de Beer ${ }^{2}$, Paulette Bloomer ${ }^{1}$, Michael J. Wingfield ${ }^{1}$, Xu \\ Dong $\mathrm{Zhou}^{3}$ and Brenda D. Wingfield ${ }^{1}$
}

(1) Department of Genetics, Forestry and Agricultural Biotechnology Institute (FABI), University of Pretoria, Pretoria 0002, South Africa.

(2) Department of Microbiology and Plant Pathology, Forestry and Agricultural Biotechnology Institute (FABI), University of Pretoria, Pretoria 0002, South Africa.

(3) China Eucalypt Research Centre (CERC), Chinese Academy of Forestry, Zhanjiang, People's Republic of China.

\section{Z. Wilhelm de Beer}

Email: wilhelm.debeer@fabi.up.ac.za

\begin{abstract}
Ophiostoma species such as $O$. quercus are the most frequent causal agents of sapstain of freshly felled hardwood timber and pulpwood. Many species are regarded as economically important agents of wood degradation. The aim of this study was to identify a collection of Ophiostoma isolates, resembling O. quercus, found on stained Eucalyptus pulpwood chips in China. DNA sequences of the internal transcribed spacer regions, including the $5.8 \mathrm{~S}$ region, of the ribosomal DNA, and parts of the $\beta$-tubulin and elongation factor- $1 \alpha$ genes, revealed that the isolates were not $O$. quercus. Surprisingly, they represented $O$. tsotsi, a wound-infesting fungus recently described from hardwoods in Africa. In addition, sequence data from an isolate from agarwood in Vietnam, identified in a previous study as belonging to an unknown Pesotum species, were also shown to represent $O$. tsotsi. A high level of genetic variability was observed among isolates of both $O$. quercus and $O$. tsotsi. This was unexpected and suggests that both species have been present in Asia for a significant amount of time.
\end{abstract}

\section{Introduction}

Eucalyptus spp. are becoming increasingly widely planted in plantations in many countries to produce a sustainable source of timber. This is largely due to their superb wood qualities, adaptability to a wide range of different environments, and their rapid growth (Turnbull 2000). They are planted extensively in Southeast Asia where the timber is mainly used for paper, oil, and pulp production. About $30 \%$ of China's 175 million ha of forests are commercial plantations, approximately 2 million ha of which consist of Eucalyptus and Corymbia species, hybrids, and clones (Anonymous 2006).

Diseases present one of the greatest threats to Eucalyptus plantation forestry, worldwide (Wingfield et al. 2008). In this regard, a number of known and novel forest pathogens have emerged from recent surveys on Eucalyptus in China (Butterworth and Lei 2005; Zhou et al. 2007, 2008). However, the pathogens listed in these surveys include only a single ophiostomatoid fungus and an uncharacterized Ceratocystis sp. (Zhou et al. 2008). This, despite the fact that in recent years numerous Ceratocystis and Ophiostoma species have been associated with disease and blue-stain on 
commercial Eucalyptus trees, timber, and pulpwood (De Beer et al. 2003a, b; Roux et al. 2004; Van Wyk et al. 2007; Rodas et al. 2008). These fungal infections most often occur through wounds in the bark and sapwood of trees caused by commercial harvesting practices or animal damage (Roux and Wingfield 2009). The exposed sapwood is susceptible to colonization by ophiostomatoid fungi, vectored by a large variety of relatively non-specific insects (Seifert 1993).

One of the ophiostomatoid fungi most frequently isolated from exposed sapwood or Eucalyptus pulpwood chips is Ophiostoma quercus (Georgev.) Nannf. (De Beer et al. 2003a, b). This species is a ubiquitous sapstain fungus primarily occurring on hardwoods, and to a lesser extent on conifers, with a global distribution (Brasier and Kirk 1993; Harrington et al. 2001; Geldenhuis et al. 2004; Thwaites et al. 2004; Zhou et al. 2004; Kamgan et al. 2008; Linnakoski et al. 2008; Nkuekam et al. 2008). The first confirmed reports of $O$. quercus from east Asia were published only during the past decade (De Beer et al. 2003b; Lin et al. 2003; Kim et al. 2005; Chung et al. 2006; Masuya et al. 2009; Paciura et al. 2010). However, it has been suggested that isolates reported as O. piceae (Münch) Syd. \& P. Syd. from several hardwood species in Japan by Nisikado and Yamauti (1935), possibly represented O. quercus (De Beer et al. 2003b).

As part of an ongoing survey of fungi infecting Eucalyptus and Corymbia species in China (Zhou et al. 2008), Eucalyptus pulpwood chips, collected in Guangdong province in the southern part of mainland China, were screened for the presence of ophiostomatoid fungi. A collection of cultures with Pesotum anamorphs reminiscent of the anamorph of $O$. quercus was isolated from the chips. The aim of this study was to determine the identity of these isolates, using culture morphology and DNA sequence comparisons of three gene regions that are regularly used to distinguish between $O$. quercus and closely related species (De Beer et al. 2003b; Linnakoski et al. 2008, 2009; Grobbelaar et al. 2009, 2010).

\section{Materials and methods}

\section{Collection and isolation of fungi}

Eucalyptus pulpwood chips were collected from a small commercial chipping factory in Leizhou, China. The wood chips were incubated in moist chambers at $25 \mathrm{C}$ until fruiting structures appeared. Isolations were made and purified as described by Kamgan et al. (2008). For reference purposes, several isolates from Eucalyptus in South Africa, and other hosts in China and elsewhere were included (Table 1). All of the isolates sequenced in this study are maintained in the culture collection (CMW) of the Forestry and Agricultural Biotechnology Institute (FABI) and a duplicate set is maintained in the China Eucalypt Research Centre (CERC).

\section{Culture and anamorph morphology}

Single spore cultures from germinating ascospores or conidia were prepared for all isolates obtained in this study. Isolates were grown on 2\% malt extract agar (MEA; Biolab, Midrand, South Africa) at room temperature for 10 days. Culture morphology was compared to descriptions of those of $O$. quercus and closely related species. Fruiting structures were mounted in lactophenol and examined using a compound microscope.

\section{DNA sequencing and phylogenetic analyses}

Genomic DNA was extracted from actively growing fungal mycelium using the method described by Linnakoski et al. (2008). The internal transcribed spacer (ITS) regions, including the 5.8S region, of the ribosomal DNA, and parts of the b-tubulin (BT) and elongation factor-1a (EF) genes were amplified using the same primers and polymerase chain reaction (PCR) conditions as those 
described by Grobbelaar et al. (2009). Contigs were assembled and sequences aligned in exactly the same manner as done by these authors. For reference purposes, published sequences of all three gene regions were obtained from GenBank for O. quercus, O. tsotsi Grobbelaar, Z.W. de Beer \& M.J. Wingf., and other species closely related to $O$. quercus. No EF sequences were available for $O$. karelicum Linnak., Z.W. de Beer \& M.J. Wingf. and O. denticiliatum Linnak., Z.W. de Beer \& M.J. Wingf. that also form part of the hardwood group in the O. piceae-complex (Linnakoski et al. 2008, 2009). Phylogenetic relationships between isolates were examined using maximum likelihood (ML) and Bayesian inference (BI) as described by Grobbelaar et al. (2009). Appropriate substitution models were selected for the two types of analyses using the Akaike Information Criterion in $\begin{array}{llllllll}\text { Modeltest } & \text { v. } 3.7 & \text { (Posada and Crandall 1998) and MrModeltest v. } 2.2\end{array}$ (http://www.abc.se/*nylander/), respectively. All trees were rooted against $O$. floccosum Math.Käärik.

Table 1. Ophiostoma isolates from Eucalyptus in China, as well as reference isolates of Ophiostoma, for which DNA sequences were determined in the present study.

\begin{tabular}{|c|c|c|c|c|c|c|c|}
\hline \multirow[t]{2}{*}{ Teleomorph } & \multirow[t]{2}{*}{ CMW no. ${ }^{2}$} & \multirow[t]{2}{*}{ Host } & \multirow[t]{2}{*}{ Origin } & \multirow[t]{2}{*}{ Collector(s) } & \multicolumn{3}{|l|}{ GenB ank } \\
\hline & & & & & ITS & BT & $\mathrm{EF}-1 \alpha$ \\
\hline \multirow[t]{4}{*}{ O. quercus } & 5679 & Acacia mearnsii & Uganda & Roux & HQ131894 & HQ131893 & FJ441265 \\
\hline & 19192 & Populus sp. & Norway & Kamgan, Solheim & HQ131895 & GQ249302 & FJ441 267 \\
\hline & 12287 & Tsuga dumosa & China & Zhou, De Beer & FJ434947 & FJ455563 & HQ131904 \\
\hline & 12298 & Salix babylonica & China & Zhou, De Beer & FJ434946 & FJ455562 & HQ131905 \\
\hline \multirow[t]{10}{*}{ O. tsotsi } & 17573 & Terminalia serecia & South Africa & Kamgan & EF408562 & FJ441255 & HQ131906 \\
\hline & 17606 & Eucalyptus grandis & South Africa & Kamgan & HQ131896 & FJ441256 & HQ131907 \\
\hline & 17618 & $E$ grandis & South Africa & Kamgan & HQ131897 & FJ441257 & HQ131908 \\
\hline & 24802 & Eucalyptus pulpwood & China & Wingfield, Zhou & HQ131898 & FJ441258 & HQ131909 \\
\hline & 24806 & Eucalyptus pulpwood & China & Wingfield, Zhou & HQ131899 & FJ441259 & HQ131910 \\
\hline & 24813 & Eucalyptus pulpwood & China & Wingfield, Zhou & HQ131900 & FJ441260 & HQ131911 \\
\hline & 24816 & Eucalyptus pulpwood & China & Wingfield, Zhou & HQ131901 & FJ441261 & NA \\
\hline & 24819 & Eucalyptus pulpwood & China & Wingfield, Zhou & HQ131902 & FJ441262 & HQ131912 \\
\hline & 24822 & Eucalyptus pulpwood & China & Wingfield, Zhou & HQ131903 & FJ441263 & HQ131913 \\
\hline & 24828 & Eucalyptus pulpwood & China & Wingfield, Zhou & NA & FJ441264 & HQ131914 \\
\hline
\end{tabular}

\section{Results}

\section{Culture and anamorph morphology}

There was substantial variability in culture and anamorph morphology among the isolates from China and elsewhere, but all corresponded broadly to culture descriptions for O. quercus (Morelet 1992; Halmschlager et al. 1994; Harrington et al. 2001), Pesotum australiae Kamgan-Nkuekam, K. Jacobs \& M.J. Wingf. (Nkuekam et al. 2008), O. denticiliatum (Linnakoski et al. 2009), and $O$. tsotsi (Grobbelaar et al. 2010). However, none of the Chinese isolates produced a teleomorph and none of the isolates could be conclusively assigned to any of the above mentioned four species based on phenotypic characters.

\section{DNA sequencing and phylogenetic analyses}

Amplicons from the partial ITS, BT, and EF gene regions, respectively, consisted of approximately 580,315 , and 330 base pairs, and the aligned data sets included 53, 48, and 41 isolates. For all three data sets the generalised time reversible (GTR) substitution model was selected as the most appropriate, with varying values for the proportion of invariable sites and gamma distribution rates. Results from the ML and BI analyses yielded concordant topologies with respect to the composition of the clades for all three gene regions. 


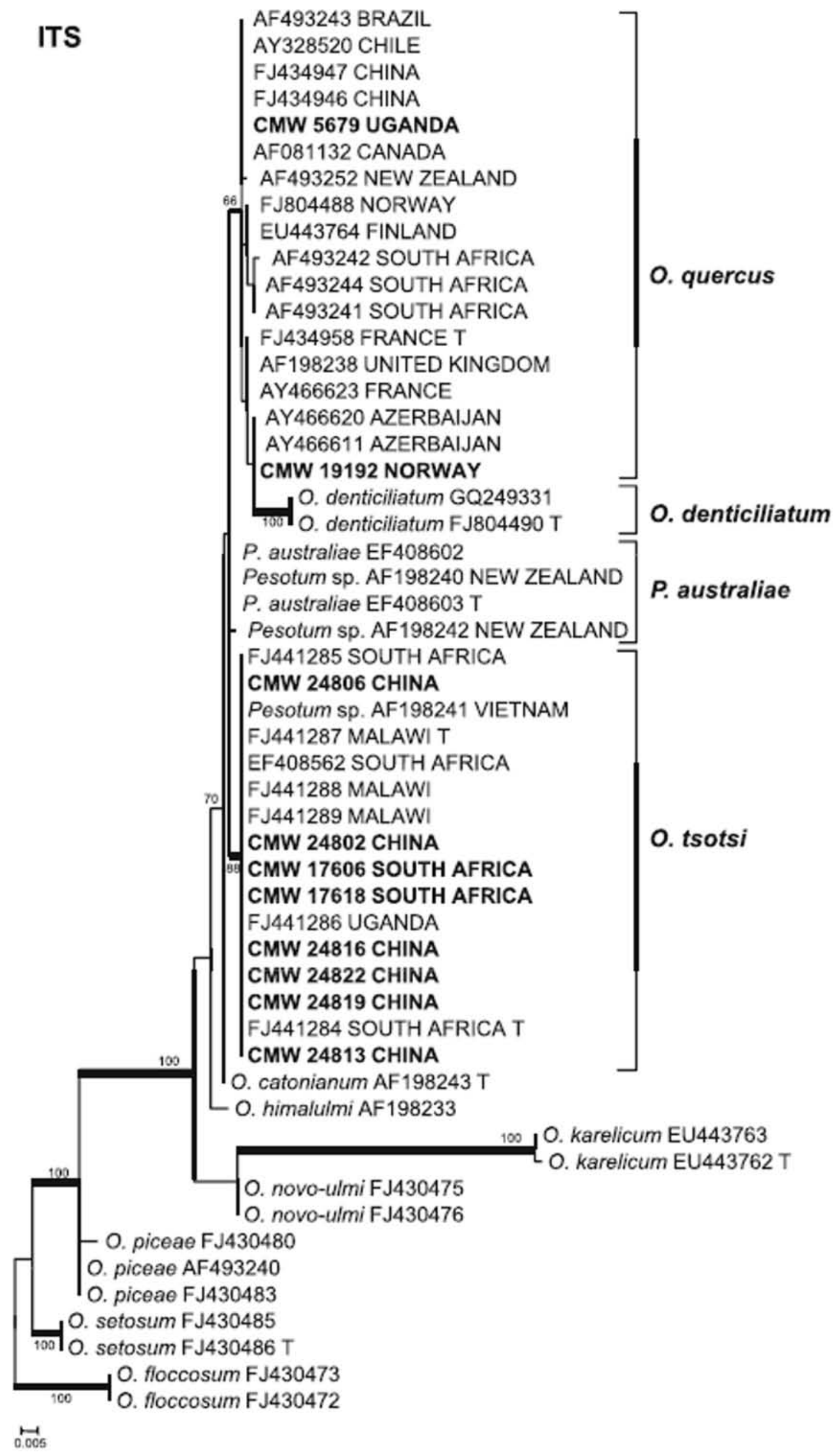


Figure 1. Phylogram resulting from a maximum likelihood (ML) analysis of the internal transcribed spacer (ITS) sequences. ML bootstrap values (1000 replicates) above $70 \%$ are given at nodes. Branches with posterior probability support values (above 90\%) obtained from Bayesian analyses are indicated with bold lines. Isolate numbers for sequences obtained in the present study are printed in bold type. $\mathrm{T}$ indicates ex-type isolates of species.

In the ITS tree (Fig. 1) O. quercus, O. denticiliatum, $P$. australiae, and $O$. tsotsi grouped together in a weakly supported monophyletic lineage. Within this lineage, only the lineages containing $O$. denticiliatum and $O$. tsotsi had significant statistical support. The Chinese isolates from Eucalyptus all grouped with the African isolates of $O$. tsotsi. A single isolate from Aquilaria crassna (agarwood) in Vietnam, labelled by Harrington et al. (2001) as an unknown Pesotum species, also grouped with the $O$. tsotsi isolates. Two other Pesotum isolates, respectively from Pinus and Nothofagus in New Zealand (Harrington et al. 2001), had identical sequences and grouped with Pesotum australiae, although these four isolates did not form a monophyletic lineage with statistical support. The lineage containing $O$. quercus isolates showed considerable variation between isolates, and did not have strong statistical support.

The BT tree (Fig. 2) showed better resolution between $O$. quercus, O. denticiliatum, P. australiae, and $O$. tsotsi, with good statistical support for all four lineages. Although the Chinese isolates from Eucalyptus did not all have identical sequences, all the isolates grouped clearly with the African $O$. tsotsi isolates. The BT sequences of both $O$. quercus and $O$. tsotsi exhibited substantial variation among isolates.

Isolates of $O$. quercus, $O$. tsotsi, and $P$. australiae formed three well-supported lineages based on the EF data (Fig. 3). The isolates from Eucalyptus in China all grouped with $O$. tsotsi. In the present study, EF sequences were also produced for two O. quercus isolates from Tsuga in China, which Paciura et al. (2010) identified based on ITS and BT sequences. These two isolates formed a subclade within the larger, well-supported $O$. quercus group. Both $O$. quercus and $O$. tsotsi lineages exhibited substantial variation in EF sequences among isolates.

\section{Discussion}

In this study, Ophiostoma tsotsi was discovered on wood of exotic Eucalyptus trees in China. This is the first time the fungus has been reported outside of Africa. Furthermore, analyses of ITS sequence data suggested that a previously collected Pesotum isolate from agarwood in Vietnam also represents $O$. tsotsi. Sequence data for both the BT and EF gene regions of $O$. tsotsi showed substantial variability within this species and the closely related O. quercus.

Ophiostoma tsotsi is phylogenetically closely related to and morphologically virtually indistinguishable from O. quercus (Grobbelaar et al. 2010). Very limited knowledge is available for this fungus, but it seems that its host range and distribution overlap with those of $O$. quercus (Harrington et al. 2001; De Beer et al. 2003b; Grobbelaar et al. 2010). Ophiostoma quercus primarily occurs on hardwoods and for many years it was considered a synonym of $O$. piceae (Münch) Syd. \& P. Syd. (Hunt 1956), which mainly occurs on conifers (Harrington et al. 2001). Mating compatibility (Morelet 1992; Brasier and Kirk 1993), growth studies (Brasier and Stephens 1993), and DNA-based techniques (Halmschlager et al. 1994; Pipe et al. 1995; Kim et al. 1999; Harrington et al. 2001; De Beer et al. 2003b), have confirmed that O. piceae and O. quercus are distinct species. Based on these results, De Beer et al. (2003b) suggested that many reports of ' $O$. piceae' on hardwoods, in the almost 40-year-period during which O. quercus was treated as a synonym of $O$. piceae, might have actually represented $O$. quercus. However, in recent studies several novel cryptic species similar to $O$. quercus have been described from hardwoods, including O. tsotsi, Pesotum australiae, and O. denticiliatum (Kamgan et al. 2008; Linnakoski et al. 2009; 


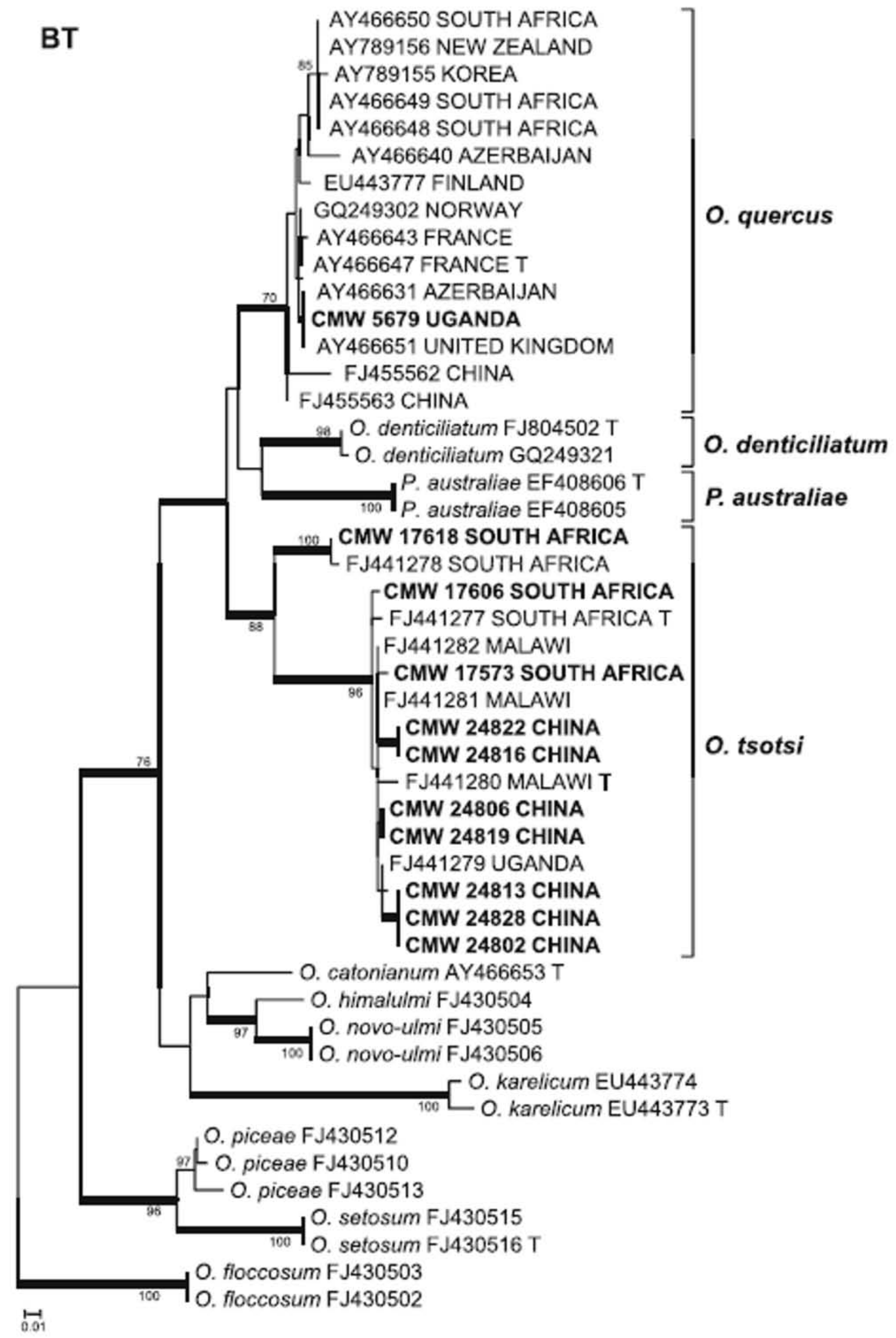


Figure 2. Phylogram resulting from a maximum likelihood (ML) analysis of the b-tubulin (BT) sequences. ML bootstrap values (1000 replicates) above $70 \%$ are given at nodes. Branches with posterior probability support values (above 90\%) obtained from Bayesian analyses are indicated with bold lines. Isolate numbers for sequences obtained in the present study are printed in bold type. $\mathrm{T}$ indicates ex-type isolates of species.

Grobbelaar et al. 2010). These studies and our results in the present study show that caution should be taken not to assume that all fungi from hardwoods that are morphologically similar to this species actually represent $O$. quercus.

Prior to this study, O. tsotsi was known only from Africa, where it is found on both exotic Eucalyptus and native hardwoods (Grobbelaar et al. 2010). Discovery of the fungus on exotic Eucalyptus in China might give the impression that the fungus was introduced into China. However, the isolate from native agarwood in Vietnam (Harrington et al. 2001) alters our perceptions regarding a possible African origin for the fungus. It is entirely possible that the fungus has been in Southeast Asia for a long time and might even be endemic to this region. The genetic variability among isolates from both Africa and China is indicative of widespread sexual recombination in both regions. More extensive sampling from native hardwoods, including eucalypts, in Australasia and Southeast Asia, and exotic eucalypt plantations in areas such as Africa and South America would be required to provide conclusive answers to questions concerning the origin of $O$. tsotsi. In this regard, the influence of host specialization and a very long history of human movement of timber across and between continents would also need to be considered.

Ophiostoma tsotsi has been isolated from fresh, exposed wounds in the cambium of living trees (Grobbelaar et al. 2010), and in the present study from stained pulpwood. At present, nothing is known regarding its pathogenicity. Like $O$. quercus, it is probably not a serious tree pathogen (Geldenhuis et al. 2004). It is more likely an insect-vectored fungus that is a primary colonist of freshly exposed sapwood and the causal agent of sapstain on felled timber. However, O. tsotsi groups within the hardwood clade of the O. piceae-complex (Harrington et al. 2001; Grobbelaar et al. 2009), relatively close to O. novo-ulmi Brasier and O. ulmi (Buisman) Nannf., the devastating tree pathogens responsible for Dutch elm disease pandemics during the last century. Thus, the possibility that $O$. tsotsi might pose a threat to living trees should not be overlooked. Apart from its pathogenicity, numerous unanswered questions remain regarding the biology and ecological role of this fungus. These questions should be addressed to ensure an accurate assessment of the risks posed by the possible introduction of $O$. tsotsi into new environments through the import and export of timber and pulpwood chips.

\section{Acknowledgements}

We thank Jolanda Roux, Gilbert Kamgan Nkuekam, and Ronald Heath for sharing the African isolates with us, and Dina Paciura for supplying some of the DNA sequences. We would like to acknowledge our African collaborators; Gerald Meke from the Forestry Research Institute of Malawi, Aza Mbaga from the Tanganyika Wattle Company, Tanzania, and the Forestry Department, Uganda, and Makerere University, Uganda. We acknowledge the National Research Foundation (NRF), members of the Tree Protection Co-operative Programme (TPCP), the THRIP initiative of the Department of Trade and Industry (DTI), and the Department of Science and Technology (DST) South Africa for financial support. This work forms part of on-going cooperation between South Africa and China, and is funded through the projects of 2007DFA31190 and 2006BAD08A11 from the Ministry of Science and Technology of China (MOST). 


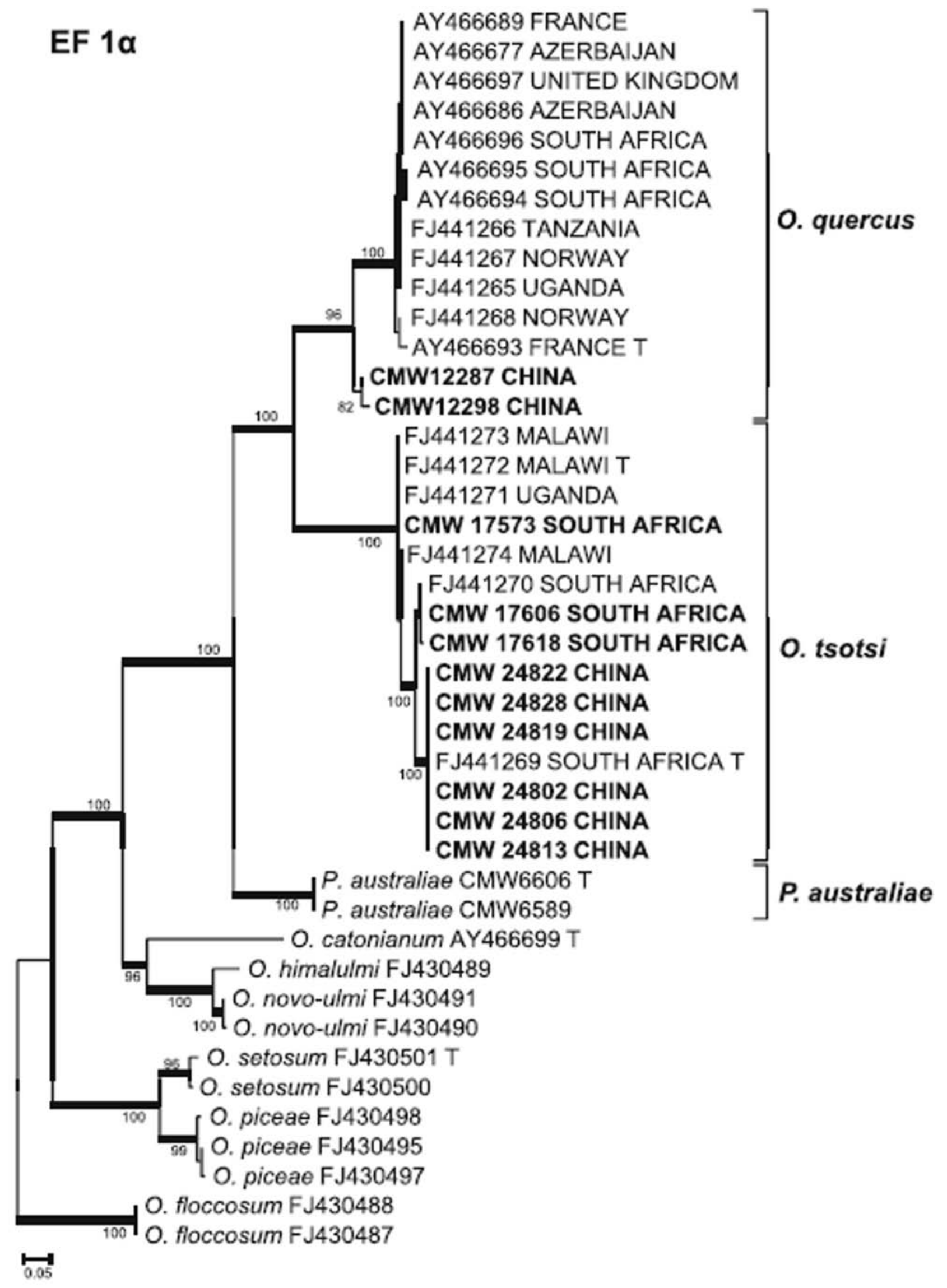

Figure 3. Phylogram resulting from a maximum likelihood (ML) analysis of the elongation factor1a (EF 1a) sequences. ML bootstrap values (1000 replicates) above $70 \%$ are given at nodes. Branches with posterior probability support values (above 90\%) obtained from Bayesian analyses are indicated with bold lines. Isolate numbers for sequences obtained in the present study are 
printed in bold type. T indicates ex-type isolates of species.

\section{References}

Anonymous (2006). The sixth survey of Chinese forestry resources. China State Forestry Administration, Beijing (in Chinese)

Brasier CM, Kirk SA (1993) Sibling species within Ophiostoma piceae. Mycol Res 97:811-816

Brasier CM, Stephens TM (1993) Temperature-growth responses distinguish the OPC and OPH sibling species within 'Ophiostoma piceae'. Mycol Res 97:1416-1418

Butterworth J, Lei Z (2005). China's sixth forest resource inventory report. USDA Foreign Agricultural Service, GAIN report number http://www.fas.usda.gov/gainfiles/200503/146119239.pdf. Accessed 17 August 2010

Chung W-H, Kim J-J, Yamaoka Y, Uzunovic A, Masuya H, Breuil C (2006) Ophiostoma breviusculum sp. nov. (Ophiostomatales, Ascomycota) is a new species in the Ophiostoma piceae complex associated with bark beetles infesting larch in Japan. Mycologia 98:801-814

De Beer ZW, Wingfield BD, Wingfield MJ (2003a) The occurrence of Ophiostoma piliferum-like fungi on pulpwood chips and other wood sources in South Africa. S Afr J Sci 99:34-36

De Beer ZW, Wingfield BD, Wingfield MJ (2003b) The Ophiostoma piceae complex in the Southern Hemisphere: a phylogenetic study. Mycol Res 107:469-476

Geldenhuis MM, Roux J, Montenegro F, De Beer ZW, Wingfield MJ, Wingfield BD (2004) Identification and pathogenicity of Graphium and Pesotum species from machete wounds on Schizolobium parahybum in Ecuador. Fungal Divers 15:135-149

Grobbelaar JW, Aghayeva D, De Beer ZW, Bloomer P, Wingfield M, Wingfield B (2009) Delimitation of Ophiostoma quercus and its synonyms using multiple gene phylogenies. Mycol Prog 8:221-236

Grobbelaar JW, De Beer ZW, Bloomer P, Wingfield MJ, Wingfield BD (2010) Ophiostoma tsotsi sp. nov., a wound-infesting fungus on hardwood trees in Africa. Mycopathologia 169:413-423

Halmschlager E, Messner R, Kowalski T, Prillinger H (1994) Differentiation of Ophiostoma piceae and Ophiostoma quercus by morphology and RAPD analysis. Syst Appl Microbiol 17:554-562

Harrington TC, McNew D, Steimel J, Hofstra D, Farrell R (2001) Phylogeny and taxonomy of the Ophiostoma piceae complex and the Dutch elm disease fungi. Mycologia 93:111-136

Hunt J (1956) Taxonomy of the genus Ceratocystis. Lloydia 19:1-58

Kamgan NG, Jacobs K, De Beer ZW, Wingfield MJ, Roux J (2008) Ceratocystis and Ophiostoma species including three new taxa, associated with wounds on native South African trees. Fungal Divers 29:37-59

Kim SH, Uzunovic A, Breuil C (1999) Rapid detection of Ophiostoma piceae and O. quercus in stained wood by PCR. Appl Environ Microbiol 65:287-290 
Kim G-H, Kim J-J, Lim YW, Breuil C (2005) Ophiostomatoid fungi isolated from Pinus radiata logs imported from New Zealand to Korea. Can J Bot 83:272-278

Lin TC, Huang JW, Hsieh WH (2003) Identification of ophiostomatoid fungi associated with Chinese fir wilt in Taiwan. Plant Pathol Bull 12:33-42 (in Chinese)

Linnakoski R, De Beer ZW, Rousi M, Niemelä P, Pappinen A, Wingfeld MJ (2008) Fungi including Ophiostoma karelicum sp. nov., associated with Scolytus ratzeburgi infesting birch in Finland and Russia. Mycol Res 112:1475-1488

Linnakoski R, De Beer ZW, Rousi M, Solheim H, Wingfield MJ (2009) Ophiostoma denticiliatum sp. nov. and other Ophiostoma species associated with the birch bark beetle in southern Norway. Persoonia 23:9-15

Masuya H, Yamaoka Y, Kaneko S, Yamaura Y (2009) Ophiostomatoid fungi isolated from Japanese red pine and their relationships with bark beetles. Mycoscience 50:212-223

Morelet M (1992) Ophiostoma querci sur chêne en France. Extrait Ann SSNATV 44:109-112

Nisikado Y, Yamauti K (1935) Contributions to the knowledge of the sap stains of wood in Japan. III. Studies on Ceratostomella piceae Münch, the cause of a blue stain of pine trees. Ohara Inst Landw Forsch Ber 6:539-560

Nkuekam GK, Jacobs K, De Beer ZW, Wingfield MJ, Roux J (2008) Pesotum australi sp. nov. and Ophiostoma quercus associated with Acacia mearnsii trees in Australia and Uganda, respectively. Australas Plant Pathol 37:406-416

Paciura D, Zhou XD, De Beer ZW, Jacobs K, Ye H, Wingfield MJ (2010) Characterisation of synnematous bark beetle-associated fungi from China, including Graphium carbonarium sp. nov. Fungal Divers 40:75-88

Pipe ND, Buck KW, Brasier CM (1995) Genomic fingerprinting supports the separation of Ophiostoma piceae into two species. Mycol Res 99:1182-1186

Posada D, Crandall KA (1998) MODELTEST: testing the model of DNA substitution. Bioinformatics 14:817-818

Rodas CA, Roux J, Van Wyk M, Wingfield BD, Wingfield MJ (2008) Ceratocystis neglecta sp. nov., infecting Eucalyptus trees in Colombia. Fungal Divers 28:73-84

Roux J, Wingfield MJ (2009) Ceratocystis species: emerging pathogens of non-native plantation Eucalyptus and Acacia species. South For 71:115-120

Roux J, Van Wyk M, Hatting H, Wingfield MJ (2004) Ceratocystis species infecting stem wounds on Eucalyptus grandis in South Africa. Plant Pathol 53:414-421

Seifert KA (1993) Sapstain of commercial lumber by species of Ophiostoma and Ceratocystis. In: Wingfield MJ, Seifert KA, Webber J (eds) Ceratocystis and Ophiostoma: taxonomy, ecology and pathogenicity. APS Press, St. Paul, pp 141-151

Thwaites JM, Farrell RL, Hata K, Carter P, Lausberg M (2004) Sapstain fungi on Pinus radiata logs — from New Zealand Forest to export in Japan. J Wood Sci 50:459-465 
Turnbull JW (2000) Economic and social importance of eucalypts. In: Keane PJ, Kile GA, Podger FD, Brown BN (eds) Diseases and pathogens of eucalypts. CSIRO Publishing, Collingwood, Australia, pp 1-9

Van Wyk M, Pegg G, Lawson S, Wingfield MJ (2007) Ceratocystis atrox sp. nov. associated with Phoracantha acanthocera infestations on Eucalyptus grandis in Australia. Australas Plant Pathol 36:407-414

Wingfield MJ, Slippers B, Hurley BP, Coutinho TA, Wingfield BD, Roux J (2008) Eucalypt pests and diseases: growing threats to plantation productivity. South For 70:139-144

Zhou XD, De Beer ZW, Ahumada R, Wingfield BD, Wingfield MJ (2004) Ophiostoma and Ceratocystiopsis spp. associated with two pine-infesting bark beetles in Chile. Fungal Divers 15:261-274

Zhou XD, De Beer ZW, Xie YJ, Pegg GS, Wingfield MJ (2007) DNA-based identification of Quambalaria pitereka causing severe leaf blight of Corymbia citriodora in China. Fungal Divers 25:245-254

Zhou XD, Xie Y, Chen S, Wingfield MJ (2008) Diseases of eucalypt plantations in China: challenges and opportunities. Fungal Divers 32:1-7 